\title{
PENGGUNAAN SIMULATOR WIPER DAN WASHER UNTUK MENINGKATKAN PEMAHAMAN KELISTRIKAN KENDARAAN RINGAN SISWA SMK
}

\author{
Yana B. Santoso ${ }^{1}$, Tatang Permana ${ }^{2}$, Ibnu Mubarak ${ }^{3}$ \\ Universitas Pendidikan Indonesia \\ Jl. Dr. Setiabudhi No. 229 Bandung 40154 \\ yanabilly47@gmail.com
}

\begin{abstract}
ABSTRAK
Tujuan penelitian ini untuk mengetahui peningkatan hasil belajar peserta didik dengan menggunakan media pembelajaran simulator wiper dan washer. Penelitian ini menggunakan metode penelitian pre-experimental dengan jenis one group pretest posttest. Instrumen penelitian menggunakan tes yang telah divalidasi oleh ahli materi dan media. Responden penelitianini sebanyak 37 orang siswa SMK. Hasil penelitian diperoleh bahwa hasil belajar dengan menggunakan simulator rata-rata naik dengan rata-rata 81. Indeks peningkatan hasil belajar sebesar 0,58 yang menunjukkan cukup baik. Kesimpulan penelitian ini bahwa pembelajaran dengan simulator wiper dan washer memiliki pengaruh terhadap peningkatan hasil belajar peserta didik.
\end{abstract}

Kata kunci: media pembelajaran, simulator wiper dan washer, hasil belajar.

\section{PENDAHULUAN}

Sekolah Menengah Kejuruan (SMK) sebagai bagian terpadu dari sistem pendidikan nasional. SMK mempunyai peranan penting dalam menyiapkan dan mengembangkan sumber daya manusia. Lulusan SMK disiapkan sesuai dengan bidangnya sebagai tenaga kerja di industri atau menciptakan lapangan pekerjaan secara profesional dan kompetitif. Tujuan SMK menurut Direktorat Pembinaan Sekolah Menengah Kejuruan adalah mendidik sumber daya manusia yang mempunyai etos kerja dan kompetensi berstandar nasional. Upaya untuk mewujudkan lulusan yang siap kerja dan kompeten harus didukung dengan sarana dan prasarana yang baik, serta proses belajar yang baik pula (Munir, 2010).

Perkembangan teknologi dan informasi di dunia pendidikan membawa dampak positif. Adanya perkembangan teknologi informasi, dunia pendidikan menjadi lebih baik. Hal itu ditandai adanya inovasi dalam penggunaan media pembelajaran dalam dunia pendidikan (Riyanto, 2010). Penggunaan media pembelajaran yang tepat dapat memberi manfaat bagi peserta didik (Kurniawan dan Mujahid, 2015). Ketertarikan untuk memahami suatu materi menggunakan media pembelajaran dapat membantu peserta didik untuk menguasai materi

\footnotetext{
${ }^{1}$ Mahasiswa Departemen Pendidikan Teknik Mesin FPTK UPI

2 Dosen Departemen Pendidikan Teknik Mesin FPTK UPI

${ }^{3}$ Dosen Departemen Pendidikan Teknik Mesin FPTK UPI
} 
tersebut. Alat pelajaran yang lengkap dan tepat akan membantu lancarnya belajar siswa seperti buku di perpustakaan, laboratorium atau media-media lain (Slameto, 2010). Penggunaan media pembelajaran dalam kegiatan belajar mengajar dapat menarik perhatian peserta didik, maka penggunaan media yang tepat dengan materi ajar dapat lebih memotivasi peserta didik dalam mengikuti pelajaran.

Hasil observasi awal pada mata pelajaran Pemeliharaan Kelistrikan Kendaraan Ringan, menunjukkan bahwa pembelajaran masih dominan menggunakan metode pembelajaran ceramah. Metode ceramah adalah metode pembelajaran yang konvensional, penyampaian materi hanya bercerita sesuai apa yang ada di dalam buku (Harsono, 2009). Pembelajaran kurang efektif, apabila hanya dilakukan dengan metode ceramah. Pada saat proses pembelajaran peserta didik hanya menjadi pendengar ceramah tanpa mengelami, dan melihat sendiri apa yang disampaikan. Cara mengajar ini dapat mengabaikan minat anak, kurang menarik, kurang menyenangkan dan membuat bosan karena diperolehnya tidak melalui pengalaman yang kongkrit melainkan berdasarkan apa yang diberikan oleh guru.

Kurangnya partisipasi aktif dan interaksi peserta didik dalam proses pelaksanaan pembelajaran pada mata pelajaran Pemeliharaan Kelistrikan Kendaraan Ringan dapat menyebabkan kurangnya pemahaman peserta didik terhadap materi yang disampaikan, dan mengakibatkan rendahnya hasil belajar peserta didik (Dimyati dan Mudjiono, 2006). Tuntutan kompetensi pada mata pelajaran produktif lebih berorientasi pada outcome, yaitu kebutuhan kemampuan yang relevan di dunia kerja (industri).

Hasil belajar yang dicapai dengan menggunakan metode pembelajaran berupa ceramah memperlihatkan kondisi dimana masih banyak peserta didik yang kurang memahami materi yang diajarkan. Indikatornya adalah rendahnya hasil belajar peserta didik. Hasil yang dicapai peserta didik dalam kompetensi dasar memahami dan memelihara kerusakan ringan pada rangkaian/sistem kelistrikan, pengaman, dan kelengkapan tambahan pada mata pelajaran Pemeliharaan Kelistrikan Kendaraan Ringan (PKKR) belum mencapai maksimal (Arifin, 2012). Nilai ulangan menunjukkan sebanyak 54\%, peserta didik yang belum mencapai Kriteria Ketuntasan Minimal (KKM). Banyak peserta didik memperoleh nilai cukup. Standar atau kriteria kompetensi yang telah ditetapkan kurikulum adalah 75.

Cukup banyaknya nilai peserta didik yang tidak memenuhi standar KKM salah satunya disebabkan oleh kurangnya penggunaan media dalam proses pembelajaran. Pembelajaran dapat 
berlangsung dengan baik dan mampu mencapai tujuan pembelajaran, apabila menggunakan model/metode pembelajaran yang tepat. Hasil belajar dan proses belajar saling berkaitan satu sama lain, sebab hasil merupakan akibat dari proses (Sudjana, 2011).

Penggunaan media pembelajaran merupakan penyajian pelajaran dengan memperagakan dan mempertunjukan kepada peserta didik tentang suatu proses, situasi atau benda tertentu, baik sebenarnya atau hanya tiruan (Sadiman, 2010). Media pembelajaran dipergunakan pada materi yang memerlukan peragaan, simulasi, atau percobaan. Pembelajaran ini berhubungan dengan keterampila proses (psikomotor) yang diperagakan agar pembelajaran bermakna lebih mendalam. Media pembelajaran dapat memperjelas pesan dan informasi sehingga dapat memperlancar dan meningkatkan proses dan hasil belajar (Azhar, 2011).

Penerapan media pembelajaran pada kompetensi dasar Memahami dan Memelihara Kerusakan Ringan Pada Rangkaian/Sistem Kelistrikan, Pengaman, dan Kelengkapan Tambahan yaitu dalam bentuk media pembelajaran simulator wiper dan washer depan. Penggunaan media pembelajaran ini diharapkan, setiap peserta didik dapat mengetahui proses kerja, gerakan dari setiap komponen dan memahami rangkaian kelistrikan yang bekerja dalam media pembelajaran simulator wiper dan washer depan (Sanjaya, 2014). Pembelajaran diharapkan menjadi aktif dan meningkatkan aktifitas belajar di kelas. Peserta didik dapat mempraktikan sendiri sehingga pembelajaran bermakna lebih mendalam. Peserta didik tidak berangan-angan lagi mengenai bagaimana kerja setiap komponen, memahami rangkaian yang bekerja, memahami dan dapat melakukan pemeliharaan kerusakaan ringan yang terjadi.

\section{METODE PENELITIAN}

Penelitian ini menggunakan metode pre-experimental design dengan jenis one group pretest-posttest. Metode pre-experimental design merupakan metode eksperimen yang belum merupakan eksperimen sungguhan, artinya masih ada variabel lain yang membengaruhi variabel yang dipilih. Penelitian ini dilakukan pada satu kelompok tunggal, yaitu kelompok eksperimen yang mendapatkan yang mendapatkan pengajaran dengan menggunakan media pembelajaran simulator wiper dan washer depan. Jenis model experimental design penelitian yang digunakan yaitu one group pretest-posttest. Desain dilakukan dua kali pengukuran. Pengukuran pertama dilakukan sebelum kelas eksperimen dilakukan perlakuan (treatment) dan pengukuran kedua setelah dilakukan treatment pada kelas eksperimen. Pengambilan sampel tidak dilakukan 
dengan cara purposive sampling melalui random. Sampel penelitian ini adalah peserta didik SMKN 8 Bandung program keahlian Teknik Otomotif, paket keahlian Teknik Kendaraan Ringan (TKR) berjumlah 37 orang.

\section{HASIL PENELITIAN}

Hasil pretest dilakukan terlebih dahulu sebelum dilakukan treatment menggunakan media pembelajaran simulator wiper dan washer depan untuk mengukur kemampuan awal peserta didik. Hasil pretest rata rata peserta didik 52 (kategori nilai D) dengan nilai terkecil 40, nilai terbesar 72. Nilai pretest peserta didik rendah. Mayoritas peserta didik memperoleh nilai dengan kategori D atau di bawah 55. Hal ini menunjukkan tidak ada satu orang pun peserta didik yang memahami kompetensi yang diujikan dan masuk ke dalam kategori tuntas. Hasil posttest dilakukan setelah peserta didik mendapatkan treatment menggunakan media pembelajaran simulator wiper dan washer depan untuk mengukur kemampuan akhir peserta didik.

Hasilnya menunjukkan bahwa nilai posttest peserta didik mengalami peningkatan dibandingkan pada nilai pretest. Hal ini ditunjukkan oleh perolehan nilai rata rata 81 dan nilai tertinggi 96, nilai terendah 68. Perolehan nilai rata rata posttest 81 dengan kategori nilai B dan 91\% perolehan nilai hasil belajar peserta didik menggunakan media pembelajaran simulator wiper dan washer depan melebihi keriteria kelulusan minimal. Hampir seluruh peserta didik memperoleh nilai hasil belajar dengan predikat B- sampai dengan A. Ada tiga orang yang mendapatkan nilai C. Hasil belajar peserta didik yang didapat dari pretest ke posttest setelah menggunakan media pembelajaran simulator wiper dan washer depan mengalami peningkatan.

\section{PEMBAHASAN}

Hasil data yang diambil dari pretest dan posttest, didapat perbedaan rata rata peningkatan hasil belajar pada kompetensi penghapus/pembersih kaca. Nilai postest lebih besar dari pada nilai prettest, nilai $\mathrm{N}$-Gain yang didapat sebesar 0,58 dengan predikat sedang dan persentase kriteria ketuntasan hasil belajar sebesar 91\% dengan predikat tuntas. Hasil belajar 20 orang peserta didik termasuk kedalam kategori sedang. Ada 9 orang peserta didik termasuk kedalam kategori tinggi dan 4 orang peserta didik termasuk kedalam kategori Rendah. N-Gain peserta 
didik terhadap media pembelajaran simulator wiper dan washer depan menunjukkan kategori sedang dengan rata rata $\mathrm{N}-$ Gain sebesar 0,58 .

Kriteria menunjukkan peningkatan hasil belajar dengan penerapan media pembelajaran simulator wiper dan washer depan berada pada kriteria sedang yaitu memenuhi skor $N$-gain $0,30 \leq N$-gain $\leq 0,70$ dengan nilai 0,58 . Penerapan media pembelajaran simulator wiper dan washer depan dapat meningkatkan hasil belajar peserta didik (Sori, et. al., 2015). Media dapat digunakan sebagai penyampai pesan yang efektif dari sumber belajar ke peserta didik (Fauzi, et. al., 2014). Hal ini seperti yang dikemukakan. Media membawa pesan-pesan atau informasi yang bertujuan intruksional atau mengandung maksud-maksud pengajaran (Arsyad, 2009). Media pembelajaran dapat memperjelas penyajian pesan dan informasi sehingga dapat memperlancar dan meningkatkan proses dan hasil belajar (Daryanto, 2016).

Peningkatan hasil belajar dari pretest ke posttest setelah dilakukan treatment berupa penerapan media pembelajaran simulator wiper dan washer depan, dengan nilai rata rata peserta didik 52 meningkat menjadi 81. Temuan peneliti diketahui bahwa penggunaan media pembelajaran simulator wiper dan washer memberikan pengaruh terhadap hasil yang diperoleh peserta didik dalam perolehan nilai posttest. Media pembelajaran dapat memperjelas penyajian pesan dan informasi sehingga dapat memperlancar dan meningkatkan proses dan hasil belajar (Radityan, et. al., 2014). Media pembelajaran dalam penelitian ini berupa simulator wiper dan washer depan dapat memperjelas penyampaian pesan atau informasi yang diberikan dan dapat memberikan peningkatan proses pembelajaran serta hasil belajar (Rudiawan, et. al., 2015). Media pembelajaran meningkatkan proses pembelajaran yang artinya memberikan pengalaman langsung pada peserta didik terhadap hal yang akan dipelajari sehingga diharapkan berdampak pada peningkattan hasil belajar peserta didik (Masitoh, et. al., 2015).

\section{KESIMPULAN}

Hasil belajar dengan menggunakan media pembelajaran wiper dan washer depan pada Mata Pelajaran Pemeliharaan Kelistrikan Kendaraan Ringan meningkata dengan signifikan. Peningkatan hasil belajar peserta didik dengan nilai $N$-Gain termasuk ke dalam kategori sedang.

\section{REFERENSI}

Arifin, Z. (2012). Evaluasi pembelajaran. Bandung: Remaja Rosdakarya. 
Arsyad, A. (2009). Media pembelajaran. Jakarta: PT. Raja Grafindo Persada.

Azhar, A. (2011). Media Pembelajaran. Jakarta: Rajawali Pers.

Daryanto. (2016). Media Pembelajaran. Yogyakata: Gava Media.

Dimyati dan Mudjiono. (2006). Belajar dan Pembelajaran. Jakarta: Rineka Cipta.

Fauzi, F., Rohendi, D., dan Yayat. (2014). Penggunaan Media Animasi untuk Meningkatkan Hasil Belajar Siswa pada Kompetensi Dasar Menggunakan Alat Ukur Berskala di SMK. Journal of Mechanical Engineering Education, 1(1), 55-64.

Kurniawan, K. dan Mujahid, A. (2015). Pengembangan Media Pembelajaran Alat Peraga pada Sistem Starter Mobil untuk Meningkatkan Hasil Belajar Siswa di SMK Cipta Karya Prembun. Jurnal Pendidikan Teknik Mesin Otomotif, 15-20.

Masitoh, U., Haryadi, dan Purnawan. (2015). Penerapan Media Pembelajaran Animasi sebagai Upaya untuk Meningkatkan Hasil Belajar Mata Kuliah Otomasi. Journal of Mechanical Engineering Education, 2(1),145-151.

Munir. (2010). Kurikulum Berbasis Teknologi Informasi dan Komunikasi. Bandung: Alfabeta.

Radityan, F. T., Kuntadi, I., dan Komaro, M. (2014). Pengaruh Multimedia Interaktif terhadap Hasil Belajar Siswa pada Kompetensi Perbaikan Differential. Journal of Mechanical Engineering Education, 1(2), 239-245.

Riyanto, Y. A. (2010). Paradigma Baru Pembelajaran. Jakarta: Kencana.

Rudiawan, D., Hamidah, I., dan Komaro, M. (2015). Pengaruh Multimedia Model Tutorial terhadap Hasil Belajar Gambar 3 Dimensi Siswa SMK. Journal of Mechanical Engineering Education, 2(1), 23-33.

Sadiman, S. (2010). Media Pendidikan. Jakarta: Raja Grapindo Persada.

Sanjaya, W. (2014). Media Komunikasi Pembelajaran. Bandung: Kencana.

Slameto. (2010). Belajar dan Faktor-faktor yang Mempengaruhinya. Jakarta: PT. Rineka Cipta.

Sori, A., Siregar, S., dan Komaro, M. (2015). Pengaruh Penggunaan Multimedia Interaktif Terhadap Hasil Belajar pada Kompetensi Proses Mesin Konversi Energi Siswa SMK. Journal of Mechanical Engineering Education, 2(1), 1-11.

Sudjana, N. (2011). Penilaian Hasil Proses Belajar Mengajar. Bandung: PT. Remaja Rosda Karya. 